\title{
Retraction: Seismic performance of tuned mass damper on Shazand Railway Bridge induced by train
}

\author{
R. Latifi ${ }^{1}$, R. Razani ${ }^{2}$ \\ ${ }^{1}$ School of Civil Engineering, Shiraz University of Technology, \\ Podonak str., 14, Shiraz, Iran, Tel. 98-0917-100-2630 \\ ${ }^{2}$ School of Civil Engineering, Shiraz University, Shiraz, Iran \\ ${ }^{1}$ Corresponding author \\ E-mail: ${ }^{1}$ r.latifi@sutech.ac.ir, ${ }^{2}$ razani@shirazu.ac.ir \\ DOI https://doi.org/10.21595/jme.2018.20013
}

Check for updates

\section{Publisher's note regarding paper}

Latifi R., Razani R. Seismic performance of tuned mass damper on Shazand Railway Bridge induced by train. Journal of Measurements in Engineering, Vol. 3, Issue 3, 2015, p. 55-62.

\section{The description of the retraction}

Retraction Date: June 5, 2018

Retraction Requested By: Editor in Chief and the Publisher

Retraction Type: Plagiarism

This paper is retracted because it fully coincides with the paper published in 2012 (listed below) without any permission from authors, or even citing the paper.

A. J. Zargani, A. K. Ghorbani-Tanha, M. S. Marefat Reducing Train-Induced Vibrations of Talezang Railway Bridge Using Tuned Mass Damper. 2nd International Conference on Acoustics and Vibration (ISAV2012), Tehran, Iran, 26-27 December, 2012.

The Publisher has checked the retracted paper for similarity issues using plagiarism detection software, however the mentioned paper was not listed in the similarity report. The similarity issues were raised by the authors of the retracted paper.

Considering recommendations from the Committee on Publication Ethics (COPE) this case was clarified as plagiarism. 